\title{
Correction to: Transforming a paediatric ICU to an adult ICU for severe Covid-19: lessons learned
}

\author{
Maryline Chomton ${ }^{1} \cdot$ Lucile Marsac $^{2}$ - Anna Deho ${ }^{1}$ - Arielle Maroni ${ }^{1,3} \cdot$ Guillaume Geslain $^{1,3}$. \\ Karine Frannais-Haverland ${ }^{1}$ • Robert-Debré University Hospital Study Group • Armelle Nicolas-Robin ${ }^{4}$. \\ Michaël Levy ${ }^{1,3}$
}

Published online: 29 March 2021

(C) Springer-Verlag GmbH Germany, part of Springer Nature 2021

\section{Correction to: European Journal of Pediatrics} https://doi.org/10.1007/s00431-021-03992-6

In the original published version of this article, the Collaborators' names were not presented in the authorship section. The names correctly presented above.

The original article has been corrected.

Authors' contributions The study group participated in data collection.

Publisher's note Springer Nature remains neutral with regard to jurisdictional claims in published maps and institutional affiliations.

The online version of the original article can be found at https://oi.org/ 10.1007/s00431-021-03992-6

Michaël Levy

levy-michael@live.fr

Maryline Chomton

maryline.chomton@aphp.fr

Lucile Marsac

lucile.marsac@aphp.fr

Anna Deho

anna.deho@aphp.fr

Arielle Maroni

arielle.maroni@aphp.fr

Guillaume Geslain

guillaume.geslain@aphp.fr
Karine Frannais-Haverland

karine.frannais@aphp.fr

Armelle Nicolas-Robin armelle.nicolas-robin@aphp.fr

1 Paediatric Intensive Care Unit, Robert-Debré University Hospital, Assistance Publique-Hôpitaux de Paris (AP-HP), Paris, France

2 Anesthesiology Department, Robert-Debré University Hospital, Assistance Publique-Hôpitaux de Paris (AP-HP), Paris, France

3 Université de Paris, Paris, France

4 Mobile Paediatric Palliative Care and Support Team, Robert-Debré University Hospital, Assistance Publique-Hôpitaux de Paris (AP-HP), Paris, France 